\title{
Influence of Meteorological Factors on Needle Cast Damage in Young Scots Pine Stands
}

\author{
Kaspars Polmanis ${ }^{1,2 *}$, Anita Baumane ${ }^{2}$, Imants Baumanis ${ }^{3}$, Solveiga Luguza ${ }^{1}$ \\ ${ }^{1}$ LLU Faculty of Forestry, Akadēmijas 11, Jelgava, LV-3001, Latvia \\ ${ }^{2}$ Latvian State Forest Research Institute „Silava”, Rīgas 111, Salaspils, LV-2169, Latvia \\ ${ }^{3}$ Forest competence centre, Dzērbenes 27, Rīga, LV-1006, Latvia
}

\begin{abstract}
Climate changes are expected to create favourable conditions for development and spread of diseases. Therefore, the impact of meteorological factors on needle cast damage, and relationship between degree of damage and growth of trees had been assessed in the study. Analysis was carried out in openpollinated progeny trial of Norupe seed orchard clones, established in the spring of 2006, in Ltd. "Rīgas meži" (LLC "Riga Forests"). In this trial needle cast damage was assessed in three consecutive years using a fivegrade scale, dependent on the level of damages on current year needles. At the end of each growing season a tree height was measured. Plantation was significantly affected by infection average more than $66 \%$ of current year damaged by the disease. Significant $(p<0.001)$ correlation was detected between the degree of needle cast damage and tree height increment as well as the tree height. Significant $(p<0.001)$ differences in needle cast infection level as well as tree height and height increment were found also between open-pollinated families. The results suggest a potentially increasing needle cast infection due to predicted increase of temperature and precipitation, as well as the potential to select more resistant families against damages of this disease in tree breeding process.
\end{abstract}

Key words: resistance, fungal infection, forest tree breeding, temperature, precipitation.

\section{Introduction}

Forest may be affected by a variety of factors - diseases, insects, climate, etc. The climate is characterized by a long-weather mode for a particular place or area and parameters like - air temperature, humidity and precipitation. Nowadays, statistics provide information about the effects of climatic changes in Latvia: over the last 50 years mean air temperature has increased by $0.8-1.4{ }^{\circ} \mathrm{C}$, while over the last 100 years it has increased by $1.5^{\circ} \mathrm{C}$. Temperature changes in the course of time have been observed mainly in spring months and winter month (December). The lower increase in temperature has been detected in June and July (Kḷavinšs et al., 2008). Also, in future a continuous climate change is predicted to increase the length of the vegetation period, as well as the sum of active temperatures and number of warm days. Global climate change has increased precipitation during the winter period, which ranges from $140 \mathrm{~mm}$ to $170 \mathrm{~mm}$ (Crookston et al., 2010, Jansons et al., 2010). Climate change will affect tree growth not only directly but also indirectly: determining the presence of various species of fungi, which in turn will affect the survival and growth of the trees, depending on their resistance against a particular pathogen.
In Latvia, needle cast disease is caused by four different pathogenic fungi - Phacidium infestans Karst., Lophodermium seditiosum Minter, Staley \& Millar and Hypodermella sulcigena (Karst.) Tub.). In recent years, in the Northern Baltics (Estonia) also other diseases significantly affecting needles are identified: Diplodia pinea (Desmo.) J. Kickx and Dothistroma septosporum (Drenkhan and Hanso, 2009).

One of the most important Scots pine (Pinus sylvestris L.) needle pathogens in nurseries and young stands (up to 24 years) are Lophodermium spp. fungi (Drenkhan, 2011), mostly Lophodermium seditiosum, which in the territory of Latvia is characterized by a high genetic diversity (Moročko-Bičevska et al., 2010) and one-year development cycle (Ortiz-García et al., 2003). If in the forest nursery infection with this fungus is not resolved, it continues to spread to young pine stands (Kḷaviņa et al., 2012). Some studies have shown that $L$. seditiosum occurrence in young stands is much less frequent than in forest nurseries (Hanso and Drenkhan, 2007). However, the wider spread of the fungi disease and a higher proportion young stands in landscape can contribute to the infection probability. Also, favourable weather conditions for this disease (Lophodermium spp.) have been observed

\footnotetext{
* Corresponding Author's email:

kaspars.polmanis@silava.lv
} 
in recent years - humid and warm autumn (as well as the end of summer) and mild winters (Martinsson, 1979, Stenström and Arvidsson, 2001). Researchers in Estonia have found that Lophodermium spp. epidemics are largely determined by the sum of precipitation from May until August in the previous year, while the average annual precipitation in autumn months, and the average air temperature in summer (except August) had no significant impact on the spread of infection (Drenkhan, 2011).

To limit the Lophodermium spp. and other needle cast diseases, fungicides should be used in forest nurseries, but in young pine stands the use of fungicides is not allowed. Therefore, in the future tree breeding (and use of selected material in forest regeneration) will have an important role in protection of young stands. The traits for selection include also resistance against needle cast damage (Baumanis et al., 1982; Liesebach and Stephan, 1996). The opportunity to select the specimens with higher resistance against needle cast damage is proven by different types of provenance experiments, because they ensure information on survival, growth and change of quality after pine seeds have been transferred to the regions with different ecological conditions. One of the first trails of this type was established at the beginning of the last century, using material from the entire distribution area of the species (Jansons et al., 2009). Analysis of information on Scots pine plantations in the former Soviet Union concluded that the number of provenances from the central part of pine distribution range has high adaptability and fast growth, because they are able to make effective use of positive changes in growth conditions (soil, climate) (Abraitis and Eriksson, 1996).

The aim of the study was to characterize the impact of temperature and precipitation on development of needle cast and its impact on tree growth.

\section{Materials and Methods}

Assessment of damages caused by needle cast was carried out in one of open-pollinated progeny trial of Norupe seed orchard 65 clones: No. 441 (hereinafter referred to as "Daugmales plantation"). Trial was established in the spring of 2006, in Ltd. "Rīgas mežì" (LLC "Riga Forests"), using one-year old seedlings in eight replicates. Planting was done in 10 tree block plots (five trees in two rows) with a spacing $1.5 \times 2 \mathrm{~m}$ (area of plot $30 \mathrm{~m}^{2}$ ). At the end of each growing season from 2007 to 2011 the height of trees was measured using a ruler (tape) with an accuracy $1 \mathrm{~mm}$. Needle cast (Lophodermium spp.) damage grade in Daugmales plantation was assessed annually in May from 2008 to 2010. From 2009 needle cast damages were evaluated only to trees in the first, second, third and fourth replication (block). Impact of this disease was evaluated in 5 grade scale, depending on the proportion of damaged brown oneyear old needles: $1^{\text {st }}$ grade - $0-5 \% ; 2^{\text {nd }}$ grade - 6-35\%; $3^{\text {rd }}$ grade $-36-65 \%$; $4^{\text {th }}$ grade -66 to $95 \%$ and $5^{\text {th }}$ grade - from 96 to $100 \%$ damaged needles.

Meteorological data - air temperature, $\left({ }^{\circ} \mathrm{C}\right)$, and precipitation, $(\mathrm{mm})$ - were obtained from the Latvian Environment, Geology and Meteorology Centre

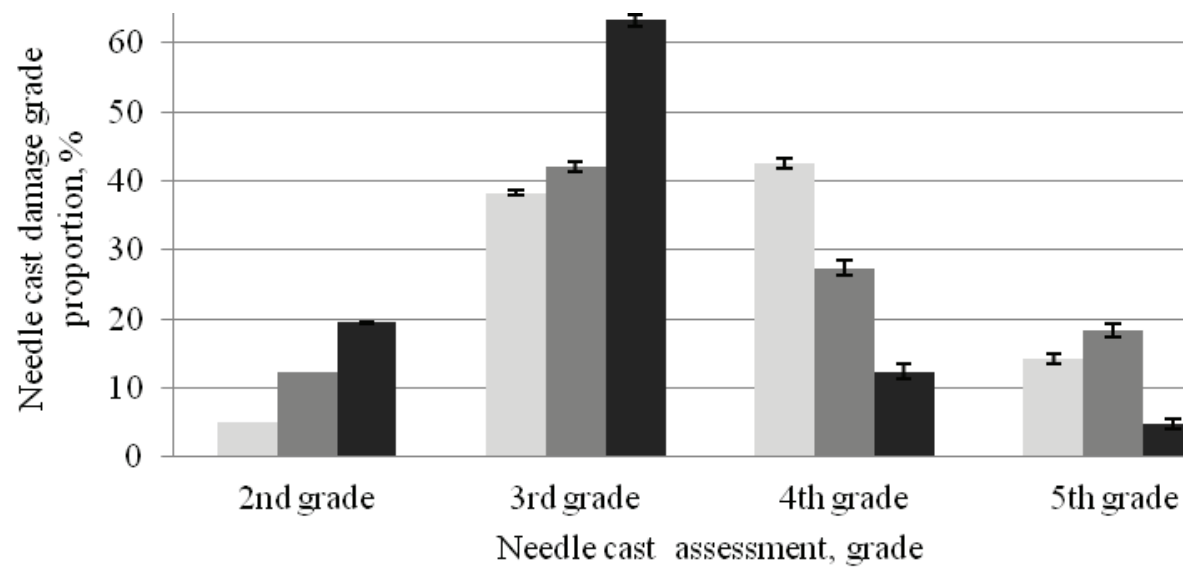

$\square 2008 \square 2009 \square 2010$

Figure 1. Proportion of trees with different needle cast damage grade $( \pm \mathrm{SE})$ over the years. 
(hereinafter referred to as "LVGMC"). To evaluate the influence of various factors on analysed traits and relationship between these traits, single factor and two-factor analysis of variance and correlation analysis were used.

\section{Results and Discussion}

In Daugmales plantation meteorological factors (temperature and precipitation) and their notable influence on needle cast damage grade were analysed. In turn, the degree of needle cast damage influenced the height increment and therefore also height of trees.

Daugmales plantation has significantly suffered from needle cast infection: the average needle cast damage grade in 2008 was 3.7 ( $\pm 0.01 \mathrm{SE})$. Analysis of variance revealed that the needle cast damage grade was significantly different between the years $(2008,2009,2010)$ both if individual tree $(p<0.001)$ (Figure 1$)$ and family mean $(\mathrm{p}<0.001)$ data were used. The start of the infection might be triggered by higher than average precipitation in 2006 and optimal temperature (Figure 2) in 2007 that ensured successful development and spread of the spores (happening during the end of summer) and notable damages of one year old needles in the following summer of the year 2008. Scientists Martinsson (1979) and Baumanis (1993) had discovered that successful spread of needle cast disease require two preconditions: first, increased precipitation in the growing season before the commencement of the epidemic, and second, the optimum temperature the year before epidemic and in the epidemic year. It creates a favourable environment for spores, contributing to their spread and development (spread) of the disease in needles.

Our results demonstrate that an increase in precipitation and temperatures have increased the number of trees that have needle cast damage grade 2 and especially 3 , but decreased the number of trees that have grades 4 and 5 . Trees with grade 1 were less than $1 \%$ of total number of trees and we were not analysing them further (Fig. 1,3.). Such a relationship can be explained by the fact that in the grade 4 and 5 the number of evaluated trees decreased due to mortality, mainly linked with needle cast infection. In turn, in grade 2 the number of assessed trees was decreased, because those, who rated with grade 2, the next year can be evaluated with the grade 3, 4 or 5, (Table1) which is explained with an increase of precipitation and air temperature (Figure 2, Figure 3).

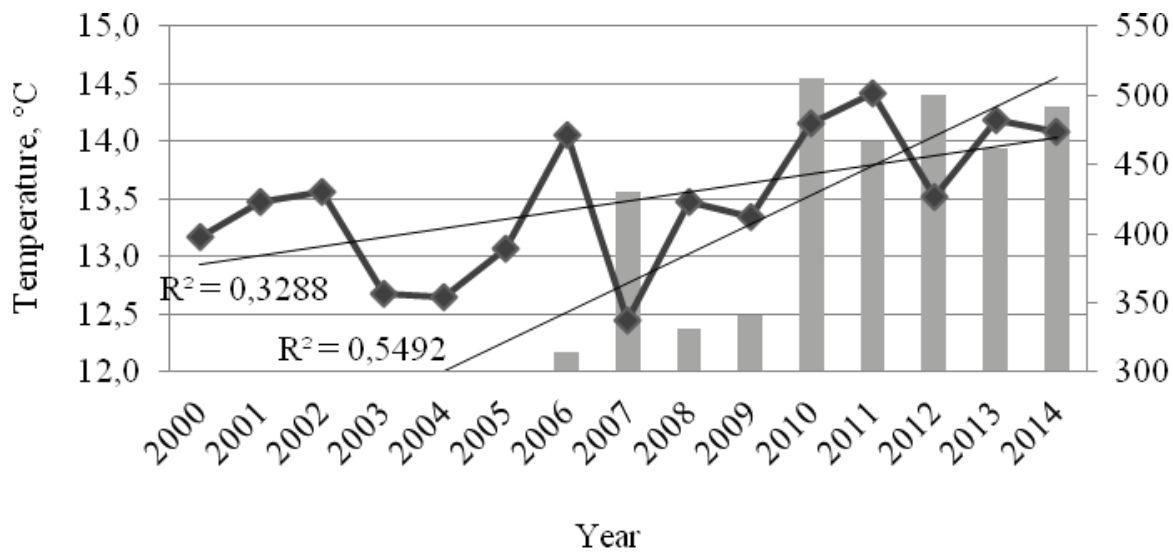

Precipitation amount in growing season

$\longrightarrow$ Average temperature in the growing season

Figure 2. Precipitation and temperature changes over the years in the growing season (April to October). 
Needle cast assessment changes

\begin{tabular}{|c|c|c|c|c|c|c|c|}
\hline \multicolumn{8}{|c|}{$2^{\text {nd }}$ grade in first assessment, 2008} \\
\hline $\begin{array}{l}\text { Grades/ } \\
\text { The proportion of } \\
\text { damaged needles }\end{array}$ & $\begin{array}{l}1^{\text {st }} \text { grade } \\
(0-5 \%)\end{array}$ & $\begin{array}{l}2^{\text {nd }} \text { grade } \\
(6-35 \%)\end{array}$ & $\begin{array}{l}3^{\text {rd }} \text { grade } \\
(36-65 \%)\end{array}$ & $\begin{array}{l}4^{\text {th }} \text { grade } \\
(66-95 \%)\end{array}$ & $\begin{array}{l}5^{\text {th }} \text { grade } \\
(96-100 \%)\end{array}$ & $\begin{array}{l}\text { Dead } \\
\text { wood, } \\
\%\end{array}$ & $\begin{array}{l}\text { Number } \\
\text { of trees } \\
2009\end{array}$ \\
\hline $2^{\text {nd }}$ grade & - & 54 & 44 & - & - & 3 & 78 \\
\hline $3^{\text {rd }}$ grade & - & 26 & 69 & 3 & - & 1 & 68 \\
\hline $4^{\text {th }}$ grade & - & 30 & 70 & - & - & - & 10 \\
\hline $5^{\text {th }}$ grade & - & - & 67 & - & 33 & - & 3 \\
\hline Dead wood, \% & - & - & - & - & - & 100 & 1 \\
\hline $\begin{array}{l}\text { Number of trees } \\
2010\end{array}$ & & 63 & 90 & 2 & 1 & 4 & 160 \\
\hline \multicolumn{8}{|c|}{$3^{\text {rd }}$ grade in first assessment, 2008} \\
\hline $2^{\text {nd }}$ grade & 1 & 45 & 53 & - & - & 1 & 158 \\
\hline $3^{\text {rd }}$ grade & - & 27 & 67 & 4 & 1 & 2 & 523 \\
\hline $4^{\text {th }}$ grade & - & 10 & 74 & 14 & 1 & 1 & 182 \\
\hline $5^{\text {th }}$ grade & - & - & 47 & 34 & 14 & 5 & 59 \\
\hline Dead wood, \% & - & - & - & - & - & 100 & 27 \\
\hline $\begin{array}{l}\text { Number of trees } \\
2010\end{array}$ & 1 & 230 & 595 & 65 & 13 & 45 & 949 \\
\hline \multicolumn{8}{|c|}{$4^{\text {th }}$ grade in first assessment, 2008} \\
\hline $2^{\text {nd }}$ grade & - & 52 & 44 & 4 & - & - & 25 \\
\hline $3^{\text {rd }}$ grade & - & 20 & 72 & 5 & - & 2 & 305 \\
\hline $4^{\text {th }}$ grade & - & 9 & 74 & 13 & 3 & 2 & 330 \\
\hline $5^{\text {th }}$ grade & - & 1 & 39 & 33 & 16 & 11 & 185 \\
\hline Dead wood, $\%$ & - & - & - & - & - & 100 & 51 \\
\hline $\begin{array}{l}\text { Number of trees } \\
2010\end{array}$ & 1 & 106 & 548 & 120 & 38 & 83 & 896 \\
\hline \multicolumn{8}{|c|}{$5^{\text {th }}$ grade in first assessment, 2008} \\
\hline $3^{\text {rd }}$ grade & - & 7 & 73 & 20 & - & - & 15 \\
\hline $4^{\text {th }}$ grade & - & 4 & 66 & 26 & 3 & 1 & 73 \\
\hline $5^{\text {th }}$ grade & - & - & 23 & 34 & 31 & 13 & 152 \\
\hline Dead wood, \% & - & - & - & - & - & 100 & 33 \\
\hline $\begin{array}{l}\text { Number of trees } \\
2010\end{array}$ & & 4 & 94 & 73 & 49 & 53 & 273 \\
\hline
\end{tabular}

Needle cast infection is not important; the financial consequences of the disease are linked to its influence on tree survival and height increment. Correlation between needle cast damages in 2008 and height increment at the same year as well as tree height next year (2009) was average both at family mean and individual tree level $(r=-0.6, p=0.05 ; \mathrm{r}=-0.5, \mathrm{p}=0.05$, respectively in both cases). Similar trends were observed in 2009 and 2010. It can be concluded that needle cast infection significantly reduced the height 


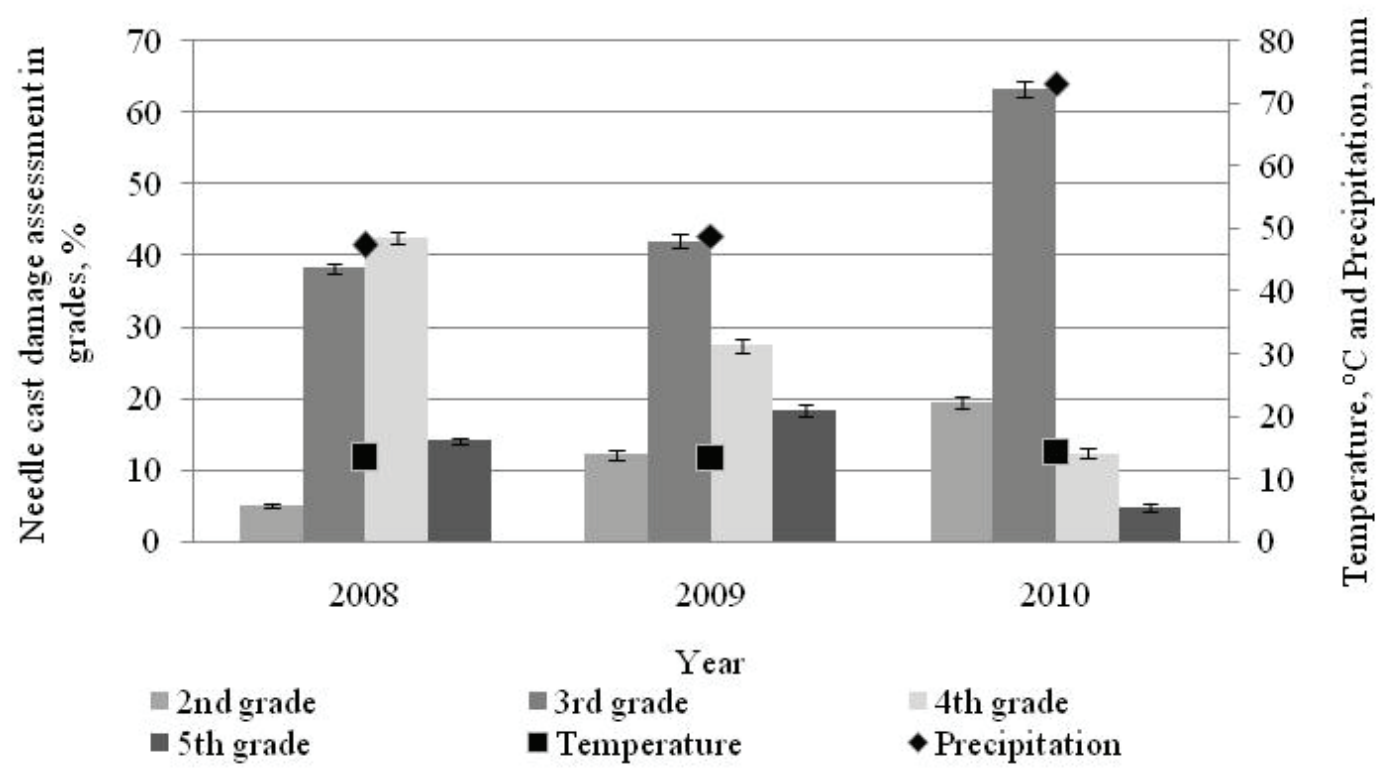

Figure 3. Needle cast damage assessment changes between grades over the years and their comparison with the average temperature and precipitation changes over the growing season (April to October).

increment of trees of the current year and influenced the next years' tree height Figure 4. Our results are in line with the previous findings by Staley and Nicholls (1989), Kanaskie (1990), Drenkhan, Kurkela and Hanso, (2006) and Vuorinen (2008) - they have noted that the degree of needle cast infection affects the tree growth potential due to significant damages of current year needles, which play an important role in tree growth. It is especially important for young trees, having lower needle biomass and nutrient reserves. Martinsson (1979) found a close negative correlation ( $\mathrm{r}=-0.80, \alpha=0.01)$ between the current year relative height increment and needle loss which are determined by the degree of needle cast infection.

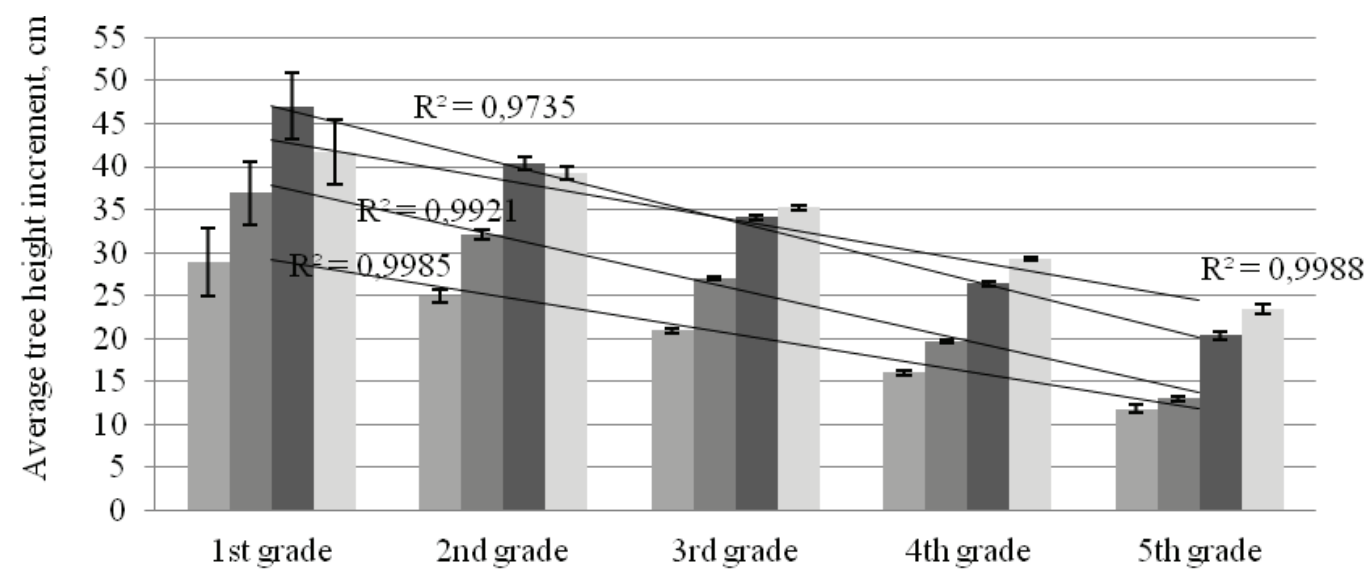

Needle cast damage grade

Average height increment 2007

average height increment 2008

-Average height increment 2009

Average height increment 2010

Figure 4. Impact of needle cast damage on height increment of trees $(\mathrm{p}<0.05)$. 
In our study needle cast damage had statistically significant impact on tree height $(\mathrm{p}<0.0003)$ and height increment $(\mathrm{p}<0.001)$. Mean height increment was lower for the trees with a higher degree of needle cast damage, and the difference increased from the first year of observed infection to the third (Figure 4). For example, difference of height increment between trees with needle cast grade 1 and grade 5 in 2007 was $17.1 \mathrm{~cm}$, but in $2009-26.6 \mathrm{~cm}$. Therefore, we can conclude that most infected trees lagged behind in the growth from year to year and resistance against needle cast damages was an important factor affecting the height of young Scots pine trees.

Our results demonstrate that resistance against the needle cast can also further be included in Scots pine breeding process, therefore improving the vitality and growth of young trees.

\section{Conclusions}

The open-pollinated progeny trial in Daugmale has significantly suffered from needle cast infection: mean needle cast damage grade was $3.7 \pm 0.01$, i.e. from 66 to $95 \%$ of current year needles were damaged by the disease. The needle cast infection had an impact on tree survival (it was lower for trees with infection grade 5) and significantly reduced height increment of current year. Cumulatively over the period of analysis ( 3 years) needle cast infection had significantly $(\mathrm{p}<0.001)$ and increasingly affected the tree height.

\section{References}

1. Abraitis, R., Eriksson, G. (1996). Pinus sylvestris L. European populations: growth and behavior in one Lithuanian field trial. Baltic Forestry, 2 (2), 28-35.

2. Baumanis, I. (1993). A complex research project: Factors in Latvia affecting the health of pine (planting stock and young plantations) and recommended protective measures. Proceeding of the Latvian Academy of Sciences, 7 (552), 79 80.

3. Baumanis, I., Pīrāgs, D., Spalviņš, Z. (1982). Resistance trials of Scots pine clones in Latvian SSR. In Heybroek, H.M., Stephan, B.R., von Weissenberg, K. (eds.). Resistance to diseases and pests in forest trees: Proceeding of the Third International Workshop on the Genetics of Host-Parasite Interactions in Forestry, 14-21 September, 1980 (pp. 448-449). Wageningen, Netherlands.

4. Crookston, N.L., Rehfeldt, G.E., Dixon, G.E., Weiskittel, A.R. (2010). Addressing climate change in the forest vegetation simulator to assess impacts on landscape forest dynamics. Forest Ecology and Management, 260, 1198 1211.
5. Drenkhan, R. (2011). Epidemiological investigation of pine foliage diseases by the use of the needle trace method. A thesis for applying of the degree of Doctor of Philosophy in Forestry, Estonian University of Life Sciences, Tartu.

6. Drenkhan, R., Kurkela, T., Hanso, M. (2006). The relationship between the needle age and the growth rate in Scots pine (Pinus sylvestris): a retrospective analysis by needle trace method (NTM). European Journal of Forest Research, 125, 397-405.

7. Drenkhan, R.,

8. Hanso, M. (2009). Recent invasion of foliage fungi of pines (Pinus spp.) to the Northern Baltics. Forestry Studies / Metsanduslikud Uurimused, 51, 49-64.

9. Hanso, M., Drenkhan, R. (2007). Retrospective analysis of Lophodermium seditiosum epidemics in Estonia. Acta Silvatica \&Lignaria Hungarica, Special Edition, 31-45.

10. Jansons, A., Almqvist, C., \& Baumanis, I. (2009). Latvijas priežu produktivitāte un kvalitāte Zviedrijā (Productivity and quality of Latvian Scots pine in Sweden). Mežzinātne, 20(53), 16-31. (In Latvian).

11. Jansons, Ā., Donis, J., \& Šmits, A. (2010). Prognozētās klimata izmaiņas Latvijā un meža adaptācijas veicināšanas iespējas. (Predicted Climate Change in Latvia and Facilitation of Wood Adaption Possibilities) Available at: http://www.zm.gov.lv/doc_upl/Klim-izm-FFKPC-A_Jansons.pdf, 4 November 2013.

12. Kanaskie, A. (1990). Lophodermium spp. Needle Cast of Scotch Pine. In Hamm, P.B., Campbell, S.J., Hansen, E.M. (eds.) Growing Healthy Seedlings: Identification and management of pests in northwest forest nurseries (34 p.). Oregon State University, Oregon, USA.

13. Kḷaviņa, D., Ķiesnere, R.D., Korica, A.M., Arhipova, N., Daugavietis, M., Gaitnieks, T. (2012). Skuju koku mizas ekstraktu ietekmes uz Lophodermium seditiosum micēlija attīstību in vitro novērtējums. (Coniferous Tree Bark Extract's Influence on Lophodermium seditiousum Mycelium Development In Vitro Assessment) Mežzinātne, 26 (59), 167.-181.

14. Kḷaviņš, M., Blumberga, D., Brunininiece, I., Briede, A., Grišule, G., Andrušaitis, A., Ābolina, K. (2008). Klimata mainība un globāiāa sasilšana. (Climate Changeability and Global Warming) Rīga: LU Akadēmiskais apgāds, 176.

15. Liesebach, M., Stephan, B.R. (1996). Results of the IUFRO 1982 Scots pine (Pinus sylvestris L.) provenance experiment in southwestern Germany. Silvae Genetica, 45, 342-349.

16. Martinsson, O. (1979). Testing Scots pine for resistance to Lophodermium needle cast. Studia Forestalia Suecica, 150, 63 p. 
17. Moročko-Bičevska, I., Fatehi, J., Baumanis, I., \& Veinberga, I. (2010). Study of brown needle cast disease of Pinus sylvestris in Latvia. In International Mycology Congress (1 p.), 1-7August, Edinburg, UK.

18. Ortiz-García, S., Gernandt, D.S., Stone, J.K., Johnston, P.R., Chapela, I.H., Salas-Lizana, R., Alvarez-Buylla, E.R. (2003). Phylogenetics of Lophodermium spp. from pine. Mycologia, 95 (5), 846-859.

19. Staley, J.M., Nicholls, T.H. (1989). Lophodermium spp. Needle Cast. In Cordell, C.E., Anderson, R.L., Hoffard, W.H., Landis, T.D., Smith, R.S. Jr., Toko, H.V.(eds.) Forest Nursery Pests (680, pp. 49-51). USDA Forest Service, Agriculture Handbook.
20. Stenström, E., Arvidsson, B. (2001). Fungicidal control of Lophodermium seditiosum on Pinus sylvestris L. seedlings in Swedish forest nurseries. Scand. J. Forest Res., 16, 147 - 154.

21. Vuorinen, M. (2008). Climatic Factors Affecting the Needle cast Epidemics Caused by Lophodermium seditiosum. In Adaptation of Forests and Forest Management to Changing Climate with Emphasis on Forest Health: A Review of Science, Policies and Practices. Book of Abstracts of International Scientific Conference (259 p.), 25-28 August, Umea, Sweden.

\section{Acknowledgements}

Authors acknowledge Una Neimane, Līga Puriña and Baiba Džering, who carried out most of the measurements in the trials. The study was conducted in Forest Competence Centre (ERDF) project «Methods and technologies for increasing forest capital value» (No. L-KC-11-0004). 